\title{
US pushes fish farming into deep water
}

Rex Dalton, San Diego

The US government is set for a confrontation with environmentalists as it investigates the viability of deep-sea fish farms in federally controlled waters.

The farms could be built more than 5.5 kilometres off the US coast - where the regulatory reach of individual states generally ends - and would keep fish in large, diamond-shaped cages about 30 metres beneath the ocean surface.

If the plan goes ahead it is likely to spark fierce opposition not just from environmental groups, but also from state officials, some of whom are already worried about the impact of shallow-water aquaculture on natural species.

The suggested sites for the farms lie in the US Exclusive Economic Zone, which extends from the edge of US territorial waters to 370 kilometres offshore. Aquaculture companies are already engaged in a "gold rush" for access to these offshore sites, says John Volpe, an ecologist at the University of Alberta in Edmonton, Canada, who is familiar with the plans. "It's like the Wild West," he says.

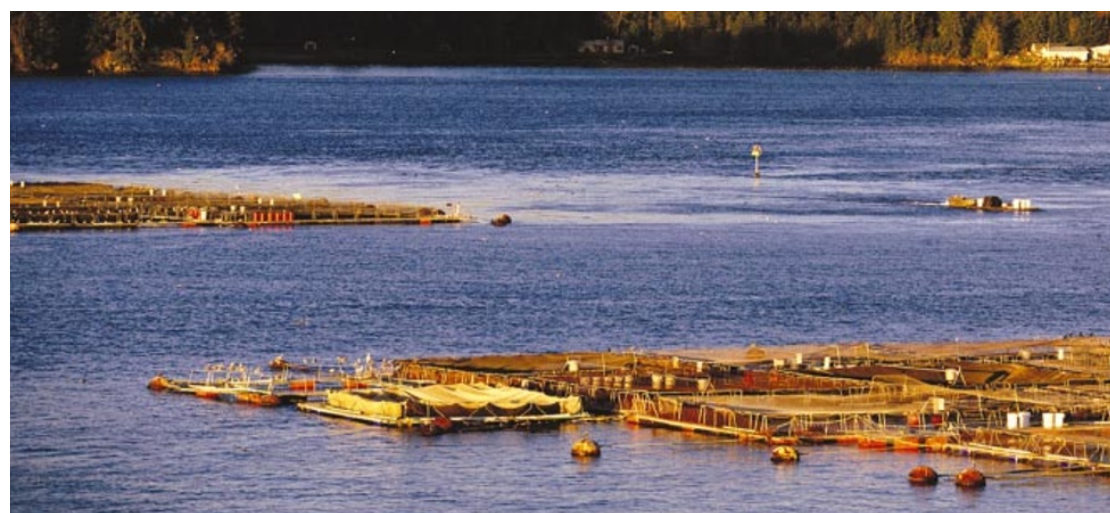

Environmentalists are worried by plans to extend aquaculture to beyond US territorial waters.

Advocates of deep-water aquaculture claim that results from preliminary research indicate that the concept is not environmentally damaging, and might reduce the ecological problems seen in near-shore fish farms. This is because the deep-water farms will be more dispersed, and further from the spawning grounds for some wild fish.

But the limited number of scientists and

\section{Pathogen-tracking questioned}

\section{Erika Check, Washington}

The US government's main programme to keep track of dangerous pathogens used in laboratories is not being run effectively, according to a Congressional investigation.

The Centers for Disease Control and Prevention (CDC), based in Atlanta, Georgia, administers the Laboratory Registration/ Select Agent Transfer Program. Under the scheme, the CDC maintains a list of deadly organisms and toxins, such as anthrax and botulinum toxin, and tracks their transfer between the hundreds of labs, at universities and elsewhere, that use them in research.

But according to the General Accounting Office (GAO), which began a review of the programme in November 2001 after the stillunsolved anthrax attacks, the CDC must do a better job of keeping tabs on these labs.

The GAO's findings were released just as the CDC prepares to revamp and increase the scope of the select agents programme.

"We found significant management weaknesses in CDC's facility registration and transfer monitoring processes that impede effective program oversight," the GAO wrote in a letter on 22 November to Tommy Thompson, head of the Department of Health and Human Services, of which the CDC is a part.

Observers say that the issues raised in the report may be addressed soon, when new regulations take effect. In June, President George Bush signed a law that, among other things, requires the $\mathrm{CDC}$ to keep track of all labs that use select agents not just those transferring the materials. On 9 December, the government will publish for public comment the regulations required by this plan, says Stephen Ostroff, deputy director of the CDC's National Center for Infectious Diseases.

The select agents programme has never been very popular: scientists resent the paperwork that it creates, and the CDC doesn't like regulating labs with which it would rather collaborate.

The CDC has also encountered delays and serious problems in administering the programme, the GAO says. Early versions of the legislation that created the new Department of Homeland Security would have wrested the entire programme from the CDC's control. But the final bill left the programme's administration unaltered. Ostroff says that the CDC has already begun to respond to the GAO's concerns by hiring more contract workers to carry out inspections, and by allocating funds to a new database.

"Everybody views this as an essential component of national security, and we're committed to running the programme as well as we can," Ostroff says. government officials aware of the plans are expressing concern. They fear that pollution from penned fish, spread of disease or parasites to wild populations, or habitat harm from inadvertent release of caged species all could harm wild fish.

Volpe says he is worried that those involved in the planning process will repeat the mistakes of near-shore salmon farming in British Columbia, where escaped and diseased fish are blamed for ecological damage.

To counter this, a number of federally funded pilot projects studying deep-water aquaculture are planned or are under way. One, examining cobia, is some $35 \mathrm{~km}$ off the coast of Mississippi in the Gulf of Mexcio.

The National Oceanic and Atmospheric Administration (NOAA) is spending $\$ 600,000$ on a study at the Center for the Study of Marine Policy at the University of Delaware to develop a policy and regulatory framework for fish farming between 5.5 and $370 \mathrm{~km}$ offshore. The three-year study will be completed in the spring, and proponents hope it will convince Congress to pass legislation allowing commercial aquaculture in this region.

And NOAA's National Marine Fisheries Service has already held workshops to develop a voluntary code of conduct for future commercial operations in the offshore belt. There also are plans to put this voluntary code into federal law, officials say.

"We are trying to fund the science for an environmental understanding of the concept," says James McVey, a marine ecologist at NOAA's Sea Grant College programme in Silver Spring, Maryland. "We hope to foster new technologies to bring to the world and the United States."

But in Alaska, where aquaculture is not permitted in state waters, scientists and government officials are fighting the plans. "NOAA should not promote aquaculture in federal waters adjacent to any state that has laws banning the practice," wrote Governor Tony Knowles in a letter to the National Marine Fisheries Service. 